\title{
Impact of selected industrial effluents on some morphological and Biochemical characteristics of Triticum aestivum $\mathbf{L}$.
}

Sajjad Ali ${ }^{*}$, Ehsan $\mathrm{Ali}^{2}$, Muhammad $\mathrm{Ali}^{3}$, Kashif $\mathrm{Ali}^{4}, \mathrm{Ikramullah}^{5}$ and Wisal Muhammad Khan ${ }^{4}$

1. Department of Botany Bacha Khan University Charsadda, KPK, Pakistan

2. Department of Biochemistry, University of Wuhan, China

3. Department of Biotechnology, Bacha Khan University Charsadda, KPK, Pakistan

4. Department of Botany Islamia college Peshawar. KPK, Pakistan

5. Department of Plant Breeding \& Genetics, Bacha Khan University Charsadda, KPK, Pakistan

*Corresponding author's email: sajjad_ali00@yahoo.com

Citation

Sajjad Ali, Ehsan Ali, Muhammad Ali, Kashif Ali, Ikramullah and Wisal Muhammad Khan. Impact of selected industrial effluents on some morphological and Biochemical characteristics of Triticum aestivum L. Pure and Applied Biology. Vol. 4, Issue 4, 2015, pp 528-534. http://dx.doi.org/10.19045/bspab.2015.44011

Received: 12/07/2015

Revised: 03/11/2015

Accepted: $12 / 11 / 2015$

\section{Abstract}

The study investigating the impact of selected industrial effluents on some morphological and biochemical characteristics of Triticum aestivum. The purpose for the study is that which effluents can be used as a low cost fertilizer. The result revealed that most of the morphological and biochemical parameters of $T$. aestivum were negatively influenced by application of concentrated effluents. The magnitude of inhibitory effects was maximum for marble industrial effluents while it was minimum for pharma industrial effluents. The pharma industrial effluents showed growth promoting effects on Triticum aestivum for some of its parameters. The paper industrial effluents also showed inhibitory effects on the test plants for both morphological and biochemical parameters which was less than marble effluents. Among the selected industrial effluents the pharma was less effective that promoted some of the morphologic and biochemical parameters of Triticum aestivum.

Keywords: Biochemical parameters; Effluents; Wheat; Morphology.

\section{Introduction}

Water stands 1 st in the list of fundamental necessities of life on the earth. Of the total water supply on earth, only $0.3-0.5 \%$ of fresh water is usable, therefore its lawful use is important [1]. Fresh water supplies are deteriorated by the addition of pollutants due to human activities. Rapid rate of urbanization, installation of industries and use of new technologies in agriculture and livestock contribute to the deterioration of water quality [2]. The urban industries dispose of their effluents and waste in streams, lakes, canals and rivers, which are undoubtedly the major sources for agriculture. Industries affect the plants quantitatively as well as qualitatively through the production of growth inhibiting substances [3].

To meet the challenge of feeding the overincreasing population of humans, the water and land resources should be used efficiently 
for crop production. To manage the food requirement, the mechanized agriculture is also playing its role for the welfare of humans. Industries contribute a lot to the deterioration of air, water and even of soil, which depends upon the type of industries installed, the type and nature of raw materials used in the industries and also the processes adopted by the industries. As industrialization and pollution are directly proportional to one another [4], some indispensable and obligatory steps must be taken for proper disposal of the wastes and pollutants. For the sustenance of life, the germination of seed and growth are very much important. Seedlings are extremely fragile and are severely affected by environmental conditions. Growth and yields are the parameter of the agriculture crop upon which the effect of the industrial effluents have been extensively investigated, but only in a few cases the effect of industrial effluents have been find out to have impact on germination. The present study was aimed to investigate the effect of three different industrial effluents located in Hayatabad industrial zone Peshawar, KPK on the morphological and biochemical parameters of $T$. aestivum.

\section{Materials and Methods}

The present study deals with the investigation of effects of the selected industrial effluents on various parameters of the Triticum aestivum L. experiment were carried out in the field.

Experiments were conducted in the botanical garden of Islamia College Peshawar. Clay pots measuring $1 \times 2$ feet were used. Each pot was filled with five $\mathrm{kg}$ loam soil. A dose of one liter of effluents of each test industry was provided to every pot from sowing till harvest at an interval of one weak. Reading of the following parameters were taken and data recorded, Length of plant stem, Number of tillers, Number of leaves, Fresh weight of plant, Dry weight of plant and Biochemical analysis of seeds.

The data were statistically analyzed by applying 2 ways ANOVA.

\section{Proximate analysis of the seeds}

Seeds of T. aestivum were obtained from the mature test crops and these seeds were analyased for Moisture, Ash, Crude fat, Crude fiber, Crude protein and for nitrogen free extract (NFE) representing the total digestible Carbohydrate [1].

\section{Results and Discussion}

Number of leaves, number of tillers, length of stem, fresh weight and dry weight of Triticum aestivum after one month of sowing.

The data collected for leaves number after one month of sowing was the highest and same to control (5.8) in treatment of pharma effluents (5.8) which showed that the effluents have neither growth promoting effect nor growth inhibiting effect on wheat. These results are in line with Dhevagi and Oblisami [7]. The number of leaves was minimum (2.6) in the treatment of paper effluents. This may be attributed to high electric conductivity [8]. In all treatment the number of tiller was affected (1.0) compared to control. So all the effluents may contain some factors which have their role in influence on the number of tillers [9]. Stem length of Triticum aestivum was also negatively affected by the effluents of the test industries (Table 1 and Fig. 1). The inhibitory effects on stem length may be attributed to the presence of some chemicals in these effluents, which interfered in the normal growth process of wheat [10]. The fresh weight was the minimum and affected $(0.626)$ more by paper effluent. This was due to formation of compact layer over the soil, which stops the growth of plants [10]. The fresh weight of plants treated with pharma effluents was more (0.786) which was due to thick stem and more number of roots. The same results were found by Arumagam (2007). The value of dry weight of $T$. aestivum was high (0.844) in the treatment of paper effluents. This was due to more biomass and organic matter. The same results were shown by Rajanan [14]. 
Table 1. Number of leaves, number of tillers, length of stem, fresh weight and dry weight of Triticum aestivum after one month of sowing.

\begin{tabular}{|l|c|c|c|c|c|}
\hline Treatments & $\begin{array}{c}\text { Number 0f } \\
\text { Leaves }\end{array}$ & $\begin{array}{c}\text { Number of } \\
\text { Tiller }\end{array}$ & $\begin{array}{c}\text { Length of } \\
\text { Stem }(\mathbf{c m})\end{array}$ & $\begin{array}{c}\text { Fresh } \\
\text { Weight }(\mathbf{g m})\end{array}$ & $\begin{array}{c}\text { Dry } \\
\text { Weight }(\mathbf{g m})\end{array}$ \\
\hline Control & $5.8 \mathrm{a}$ & $2.6 \mathrm{a}$ & $12.0 \mathrm{a}$ & $0.625 \mathrm{~b}$ & $0.109 \mathrm{~b}$ \\
\hline Pharma & $5.8 \mathrm{a}$ & $1.0 \mathrm{~b}$ & $10.8 \mathrm{a}$ & $0.786 \mathrm{a}$ & $0.448 \mathrm{ab}$ \\
\hline Marble & $3.0 \mathrm{~b}$ & $1.0 \mathrm{~b}$ & $7.8 \mathrm{~b}$ & $0.626 \mathrm{~b}$ & $0.766 \mathrm{a}$ \\
\hline Paper & $2.6 \mathrm{~b}$ & $1.0 \mathrm{~b}$ & $7.0 \mathrm{~b}$ & $0.568 \mathrm{~b}$ & $0.844 \mathrm{a}$ \\
\hline LSD value & 1.384 & 0.3774 & 1.504 & 0.1153 & 0.3970 \\
\hline
\end{tabular}

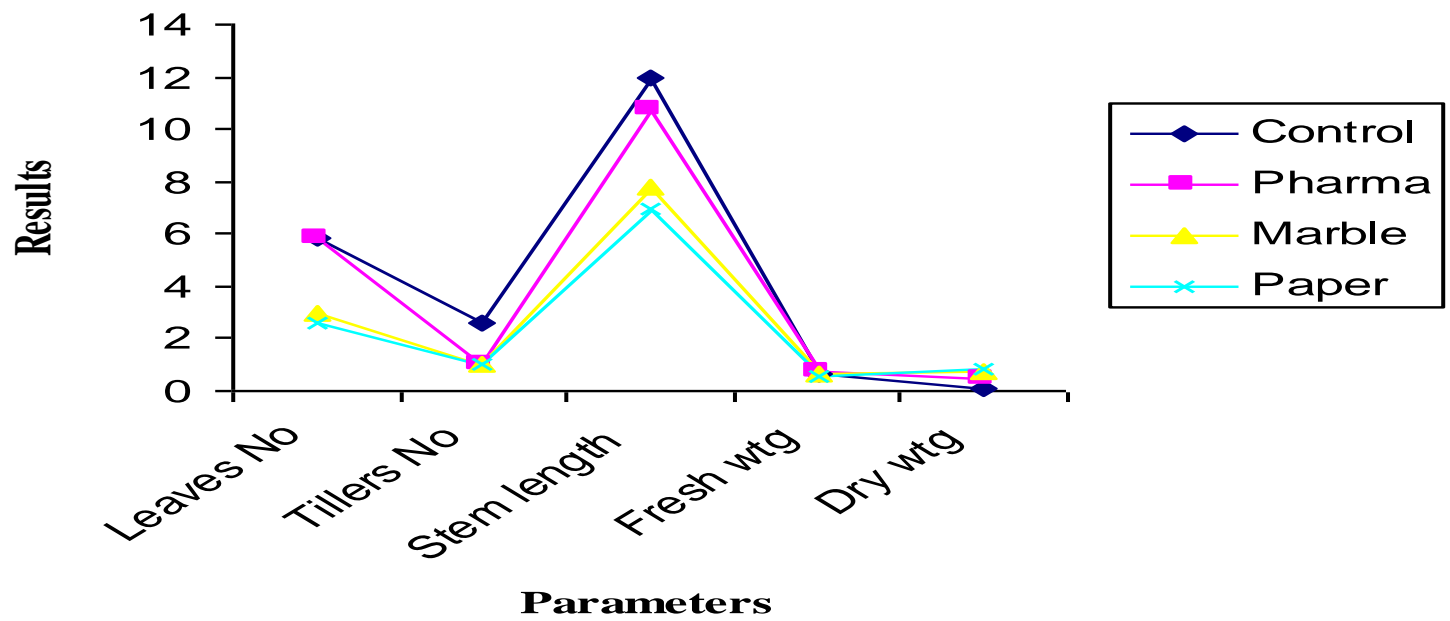

Fig 1. Number of leaves, number of tillers, length of stem, fresh weight and dry weight of Triticum aestivu $7 f \mathrm{~m}$ after one month of sowing.

Number of leaves, number of tillers, length of stem, fresh weight and dry weight of Triticum aestivum after two months of sowing.

The number of leaves in the treatment of marble effluents was the lowest (5.2) from all treatments (Table 2 and Fig. 2). This may be attributed to the presence of high value of phosphate and nitrate which negatively affected the growth of wheat [2]. There is less number of tillers in wheat in the treatment of marble effluents (6.6). The stem length of wheat in treatment of paper effluent is much affected (29.4) compared to control (46.0). This may be attributed to the high level of sodium in soil, which has bad effect on plants. The results are similar with Bhosale [4] and Nagaraj [11]. The dry weight value in the treatment of paper effluents is negatively affected (2.41) compared to control (3.054). Same results were found by Bhosale [4]. The fresh weight in treatment of paper effluents showed low value (8.986) compared to control (14.648). This might be due to high alkalinity $\mathrm{pH}$ (7.9), which may affect the fresh weight of the plant. The results are similar to Rajanan [16]. 
Table 2. Number of leaves, number of tillers, length of stem, fresh weight and dry weight of Triticum aestivum after two months of sowing.

\begin{tabular}{|c|c|c|c|c|c|}
\hline Treatments & $\begin{array}{c}\text { Numbers of } \\
\text { Leaves }\end{array}$ & $\begin{array}{c}\text { Numbers } \\
\text { of Tiller }\end{array}$ & $\begin{array}{c}\text { Length of } \\
\text { Stem(cm) }\end{array}$ & $\begin{array}{c}\text { Fresh } \\
\text { Weight }(\mathbf{g m})\end{array}$ & Dry Weight(gm) \\
\hline Control & $7.0 \mathrm{a}$ & $10.8 \mathrm{a}$ & $46.0 \mathrm{a}$ & $14.648 \mathrm{a}$ & $3.054 \mathrm{a}$ \\
\hline Pharma & $5.6 \mathrm{~b}$ & $10.2 \mathrm{a}$ & $44.8 \mathrm{a}$ & $13.778 \mathrm{a}$ & $2.70 \mathrm{ab}$ \\
\hline Marble & $5.2 \mathrm{~b}$ & $6.6 \mathrm{~b}$ & $30.4 \mathrm{~b}$ & $9.424 \mathrm{~b}$ & $2.72 \mathrm{ab}$ \\
\hline Paper & $6.4 \mathrm{a}$ & $7.0 \mathrm{~b}$ & $29.4 \mathrm{~b}$ & $8.986 \mathrm{~b}$ & $2.416 \mathrm{~b}$ \\
\hline LSD value & 0.7952 & 2.086 & 3.836 & 1.452 & 0.5007 \\
\hline
\end{tabular}

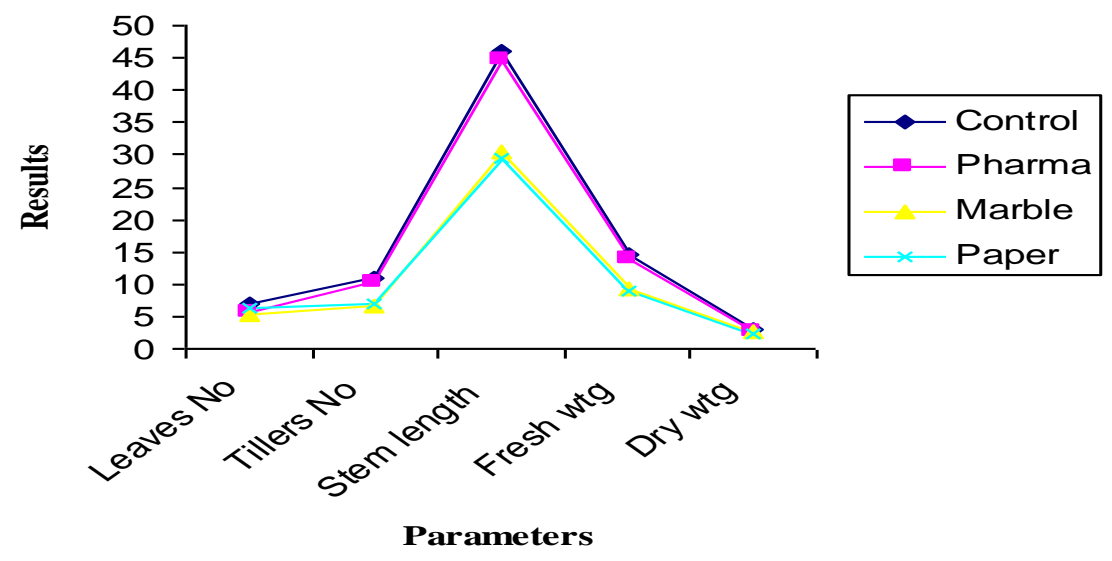

Fig 2.Number of leaves, number of tillers, length of stem, fresh weight and dry weight of Triticum aestivum after two months of sowing.

Number of leaves, number of tillers, length of stem, fresh weight, dry weight and seeds number of Triticum aestivum after harvest.

It was noted for pharma effluents that the number of leaves (10.4) and number of tillers (16.4) was enhanced as compared to all other treatments. This enhancement may be due to the presence of some growth promoting chemicals [1]. Marble effluent caused reduction in stem length (52.2), fresh weight (20.28) and dry weight (20.28) of Triticum aestivum. These effects may be attributed to the presence of Phosphorus and Calcium in extra amount [5].

In comparison to all other morphological parameters the seed number was highly affected in the marble effluents (19.4). The other morphological parameters were less affected as compared to seeds number. Pharma effluents showed highly positive affects by increasing the seed number. This enhancement was probably due to some growth promoting chemicals [12]. The LSD value showed that the results recorded for the seed number were completely significant (Table 3 and Fig. 3). 
Table 3. Number of leaves, number of tillers, length of stem, fresh weight, dry weight and seeds number of Triticum aestivum after harvest.

\begin{tabular}{|l|c|c|c|c|c|c|}
\hline Treatments & $\begin{array}{c}\text { Numbers } \\
\text { of } \\
\text { Leaves }\end{array}$ & $\begin{array}{c}\text { Numbers } \\
\text { of Tillers }\end{array}$ & $\begin{array}{c}\text { Length } \\
\text { of } \\
\text { Stem(cm) }\end{array}$ & $\begin{array}{c}\text { Fresh } \\
\text { Weight(gm) }\end{array}$ & $\begin{array}{c}\text { Dry } \\
\text { Weight(gm) }\end{array}$ & $\begin{array}{c}\text { Numbers } \\
\text { of Seeds }\end{array}$ \\
\hline Control & $9.4 \mathrm{a}$ & $11.0 \mathrm{~b}$ & $98.6 \mathrm{a}$ & $73.216 \mathrm{a}$ & $68.590 \mathrm{a}$ & $37.8 \mathrm{~b}$ \\
\hline Pharma & $10.4 \mathrm{a}$ & $16.4 \mathrm{a}$ & $95.6 \mathrm{a}$ & $61.812 \mathrm{~b}$ & $61.832 \mathrm{~b}$ & $49.4 \mathrm{a}$ \\
\hline Marble & $6.2 \mathrm{~b}$ & $7.8 \mathrm{c}$ & $52.2 \mathrm{~b}$ & $20.280 \mathrm{c}$ & $20.280 \mathrm{c}$ & $19.4 \mathrm{~d}$ \\
\hline Paper & $6.8 \mathrm{~b}$ & $8.8 \mathrm{c}$ & $57.6 \mathrm{~b}$ & $57.014 \mathrm{~b}$ & $57.014 \mathrm{~b}$ & $25.4 \mathrm{c}$ \\
\hline LSD value & 1.725 & 1.981 & 12.57 & 9.278 & 5.875 & 4.347 \\
\hline
\end{tabular}

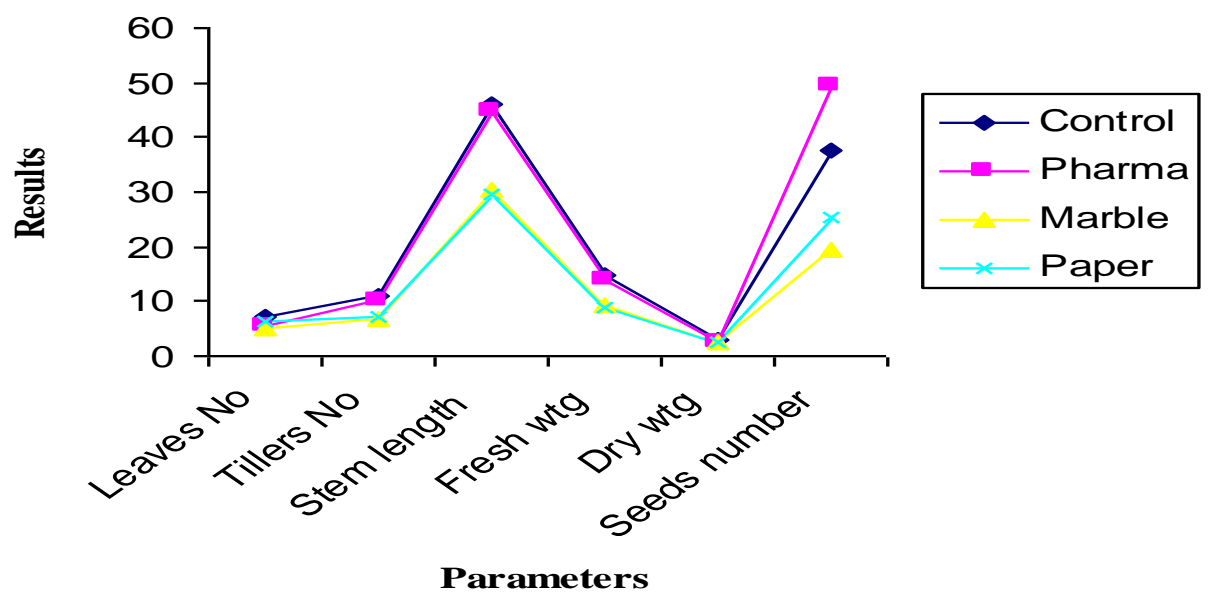

Fig. 3. Number of leaves, number of tillers, length of stem, fresh weight, dry weight and seeds number of Triticum aestivum after harvest.

Various chemical constituents of Triticum aestivum grown in industrial effluents.

Moisture

The seeds of wheat plant grown in industrial effluents were analyzed for the moisture content. The highest value of moisture was in control 5.9\% and the lowest moisture was in the seeds grown in marble effluents having $4.5 \%$, seeds in pharma effluent and in paper effluents showed the moisture content $4.7 \%$ and $5.6 \%$ respectively (Table 4 and Fig 4).

Ash

Seeds obtained from T.aestivum and $B$. juncea in industrial effluents were analyzed for ash content. The results showed that the ash percent decreased with altering the water nature from pure to dirty. The ash contents in control were $2.9 \%$ while that of pharma effluent was 2.3\% (Table 4 and Fig.4).

Crude Fats

Highest mean value of crude fat was recorded in the plants treated with marble effluents $(2.9 \%)$. Other treatments showed relative lower values.

Protein

The average protein contents of seeds found in control was $13.8 \%$. This was lower from the pharma (14.3\%) and marble effluents $(14.5 \%)$. In case of paper effluents the protein data was $13.4 \%$ which was the lowest from other treatments.

Fiber

The crude fiber analysis in the seeds of wheat showed the lowest value in control $(1.9 \%)$ and in the paper effluents $(1.87 \%)$ 
while it was maximum in the marble effluents $(2.1 \%)$ and in pharma effluents it was $2.0 \%$.

\section{Carbohydrates}

The seeds of plants grown in the effluents were analyzed for carbohydrate. The highest value was in pharma effluents that were $74.0 \%$ and the lowest value was in the marble effluents which was $72.2 \%$. Marble and paper effluents have $72.2 \%$ and $73.8 \%$ carbohydrates respectively (Table 4 and Fig.4).

Table 4. Various chemical constituents of Triticum aestivum grown in industrial effluents.

\begin{tabular}{|l|l|l|l|l|l|l|}
\hline Treatments & Moisture(\%) & $\mathbf{A s h}(\boldsymbol{\%})$ & Fat(\%) & Protein(\%) & Fibre(\%) & Carbohydrate(\%) \\
\hline Control & 5.9 & 2.9 & 2.4 & 13.8 & 1.9 & 73.1 \\
\hline Pharma & 4.7 & 2.3 & 2.7 & 14.3 & 2.0 & 74.0 \\
\hline Marble & 4.5 & 2.8 & 2.9 & 14.5 & 2.1 & 72.2 \\
\hline Paper & 5.6 & 2.7 & 2.6 & 13.4 & 1.87 & 73.8 \\
\hline
\end{tabular}

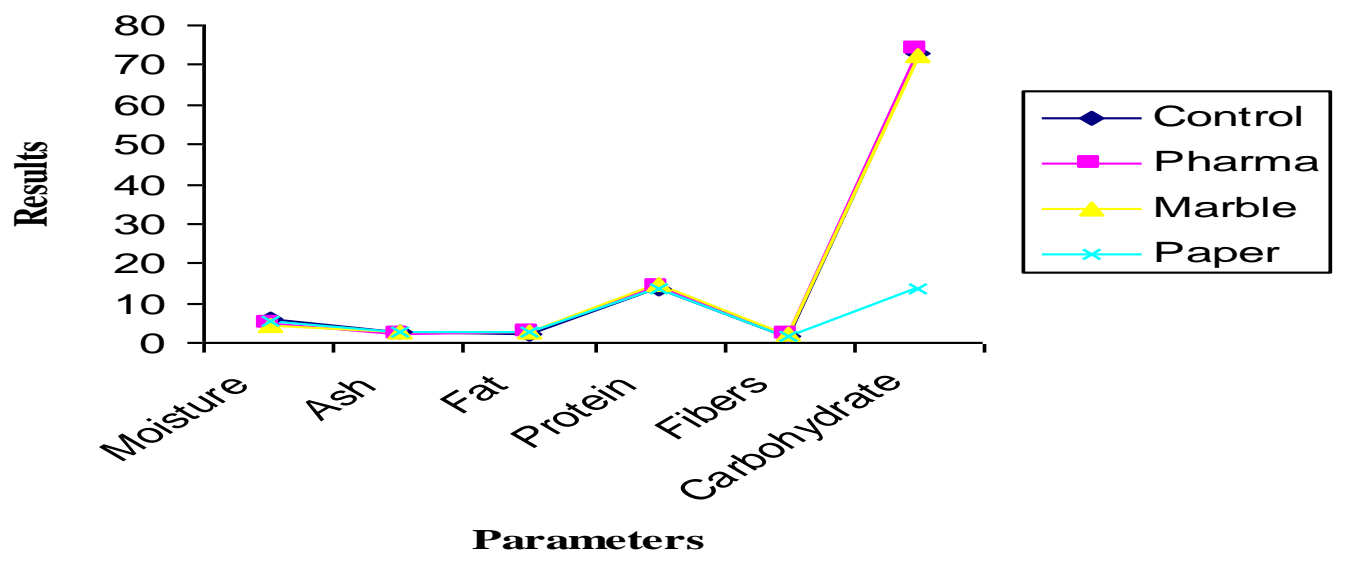

Fig. 4. Various chemical constituents of Triticum aestivum grown in industrial effluents.

\section{Conclusions}

The effluents of different industries in the eject able form affect the plants growth and its yields. These effluents disturb the complete biochemistry of economic plants and affect our economy as well as they also cause severe and dangerous diseases. So for these effluents a separate way is constructed that they did not pass near from our crops.

\section{Recommendation}

The effluents of the industries may have the beneficial effect on the plants also. If these effluents are used in their specific dilution level than it could have positive effect and can use it as a low cost fertilizer.

\section{Authors' contributions}

Carried out the experiment and the corresponding author: Sajjad Ali

Analysis of biochemical characteristics of seeds: Ehsan Ali

Effluent provider: Muhammad Ali

Help in formation of paper: Kashif Ali

Parameters calculation: Ikramullah Statistical analysis: Wisal Muhammad Khan References

1. AOAC International (2000). Official methods of analysis of the association of official analytical chemists. $17^{\text {th }}$ ed. Maryland, USA.

2. Arumagam K (2007). Impact of pharmaceutical factory effluent on 
seed germination and seedling growth of five varieties of groundnut (Arachis hypogea). Journal. Ecotoxico Eunviron. Monit 17 (3): 245-250.

3. Bal AS (1999). Waste water management for textile industry. Indian J. Environ. Hlth 41: 264-290.

4. Bhosale TA and Patil TM (2006). Effect of paper mill waste water irrigation on soil. Journal Ecobiol 18 (2): 189-191.

5. Channakeshava P, Sarangamath A and Naik A (2007). Direct and residual effect of sludge and other ' $\mathrm{P}$ ' sources on nutrient status and uptake under paddy -cowpea cropping sequence. Journal Ecotoxicol. Environ. Monit 17 (1): 73-80.

6. Datar MT (1997). Performance of dairy effluent treatment plant. Indian J. Environ. Hlth 39: 52-60.

7. Dhevagi P, and Oblisami (2000). Effect of paper mill effluent on germination of agricultural crops. Journal Ecobiol 12 (4): 243-249.

8. Elarajan M, and Jayaknmar J (2006). Effect of paper factory effluent on germination and seedling vigour of selected crops. Journal Ecobiol 19 (2): 173-183.

9. Goutam DD and Bishnoi S (1999a). Characterization of urmal dairy effluent. 13-16.

Okossay 7(12):

10. Malleshappa G (1979). Agronomic studies on the utilization of paper mill effluent in the production of soybean (Glycine $\max$ (L.) Merrill). M.Sc. (Agri.) Thesis, Uni. Agric. Sci., Bangalore (India).

11. Nagaraja DN (1987). Agronomic investigations on the utilization of raw sewage effluent in crop production. Ph. D. Thesis, Uni. Agric. Sci., Bangalore (India).

12. Prashanth R and Kannan M (2007). Effect of paper board mill sludge biocompost and Effluent irrigation on physiological attributer and yield of cowpea. Journal Ecobiol 21(4):377 382.

13. Rajanan G and Oblisamy G (1979). Effect of paper factory effluents on soil and crop plants. Indian J. Environ. Hlth 21: 120-130.

14. Singh Y and Bahadur R (1997). Effect of distillery irrigation on maize grain crop and soil fertility. Indian J. Ecol 24 (1): 53-59.

15. Sukanya TS and Meli SS (2003a). Distillery effluent as nitrogen source on maize yield and soil properties. Karnataka J. Agric. Sci 24 (3): 430445. 